\section{BIOSYNTHESIS OF MONACOLINS: CONVERSION OF MONACOLIN J TO MONACOLIN K (MEVINOLIN)}

\author{
Keisuke Kimura, Daisuke Komagata, \\ Shigeo Murakawa and AKIra Endo \\ Department of Applied Biological Sciences, \\ Tokyo Noko University, \\ Fuchu-shi, Tokyo 183, Japan
}

(Received for publication May 2, 1990)

Monacolins, which include monacolins $\mathrm{J}, \mathrm{K}$ (mevinolin), L, 4a,5-dihydromonacolin $\mathrm{L}$ and $3 \alpha$-hydroxy-3,5-dihydromonacolin L (Fig. 1), are metabolites of Monascus ruber ${ }^{1 \sim 6}$. These compounds are potent inhibitors of 3-hydroxy-3methylglutaryl coenzyme A (HMG-CoA) reductase, the rate-limiting enzyme of cholesterol biosynthesis $^{6)}$.

Previous studies have shown the conversion of 4a,5-dihydromonacolin $\mathrm{L}$ into $3 \alpha$-hydroxy-3,5dihydromonacolin $\mathrm{L}$ and monacolin $\mathrm{L}$, and hydroxylation of monacolin $\mathrm{L}$ to monacolin $\mathrm{J}$ by M. ruber ${ }^{7,8)}$. The present communication deals with the transformation of monacolin $\mathrm{J}$ to monacolin $\mathrm{K}$ by a cell-free extract of $M$. ruber and by living cells of Paecilomyces viridis. The latter fungus is known to produce compactin (ML-236B) analogs, another family of $\mathrm{HMG}-\mathrm{CoA}$ reductase inhibitors ${ }^{6}$.

$M$. ruber M4681 was grown aerobically in a medium containing glycerol $7 \%$, glucose $3 \%$, meat extract $3 \%$, peptone $0.8 \%, \mathrm{NaNO}_{3} 0.2 \%$ and $\mathrm{MgSO}_{4} \cdot 7 \mathrm{H}_{2} \mathrm{O} 0.1 \%$ at $25^{\circ} \mathrm{C}$ for 2 days. The culture broth $(100 \mathrm{ml})$ was filtered and the mycelia were washed with $50 \mathrm{~mm}$ potassium phosphate buffer, $\mathrm{pH}$ 8.3 , containing $2 \mathrm{~mm}$ EDTA. The washed mycelia $\left(1.5 \mathrm{~g}\right.$ ) were ground at $0^{\circ} \mathrm{C}$ for 5 minutes with $3 \mathrm{~g}$ of alumina and $0.8 \mathrm{ml}$ of $50 \mathrm{~mm}$ potassium phosphate buffer, pH 8.3 , containing $2 \mathrm{mM}$ EDTA, $1 \mathrm{mM}$ dithiothreitol, $1 \mathrm{~mm}$ phenylmethylsulfonyl fluoride and $0.25 \mathrm{M}$ sucrose (PS solution). The slurry was mixed with $6 \mathrm{ml}$ of PS solution and centrifuged at $1,500 \times g$ for 20 minutes. The resultant supernatant (cell-free extract) contained $15.0 \mathrm{mg}$ protein $/ \mathrm{ml}$ as determined by the method of BRADFORD ${ }^{9)}$.

A mixture $(1 \mathrm{ml})$ containing $100 \mathrm{~mm}$ potassium phosphate buffer, $\mathrm{pH} 7.0,0.1 \mathrm{mg} / \mathrm{ml}$ of monacolin $\mathbf{J}$ (acid form, obtained as described previously $\left.{ }^{4}\right)$ and $1.0 \mathrm{mg}$ protein of the cell-free extract was incubated at $25^{\circ} \mathrm{C}$ for 6 hours with gentle shaking. Incubation was terminated with TFA ( $\mathrm{pH} 2$ ) and the mixture was extracted with $1 \mathrm{ml}$ of ethyl acetate (three times). The solvent layer was evaporated to dryness under reduced pressure and submitted to HPLC using a Silica ODS column (LiChrospher RP-18, 4.0 $\times$ $250 \mathrm{~mm}$ ), which was developed with a mixture of acetonitrile $-0.1 \% \quad \mathrm{H}_{3} \mathrm{PO}_{4} \quad(55: 45)$. The results showed that $6 \%$ of monacolin $\mathrm{J}$ was converted to monacolin $\mathrm{K}$. No detectable monacolin $\mathrm{K}$ was found when incubated in the absence of monacolin $J$.

$P$. viridis $\mathrm{L}-63$ was grown at $25^{\circ} \mathrm{C}$ for 4 days in a medium containing glycerol $7 \%$ glucose $3 \%$, soy bean meal $3 \%$, peptone $0.8 \%, \mathrm{NaNO}_{3} 0.2 \%$ and $\mathrm{MgSO}_{4} \cdot 7 \mathrm{H}_{2} \mathrm{O} 0.1 \%$. The mycelia were obtained by centrifugation and suspended in $10 \mathrm{ml}$ of $50 \mathrm{~mm}$ phosphate buffer, $\mathrm{pH}$ 7.0. The mycelial suspension was incubated at $25^{\circ} \mathrm{C}$ with monacolin $\mathrm{J}$ (acid form,

Fig. 1. Monacolin analogs and their biosynthesis.

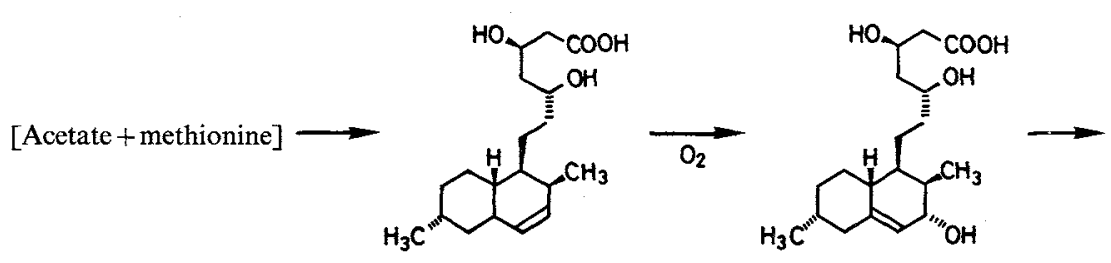

4a,5-Dihydromonacolin L $3 \alpha$-Hydroxy-3,5-dihydromonacolin L<smiles>C[C@H]1C=C2C=C[C@H](C)[C@H](CC[C@H](O)CC(=O)O)[C@H]2CC1</smiles>

Monacolin L

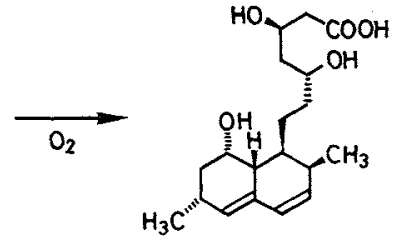

Monacolin J

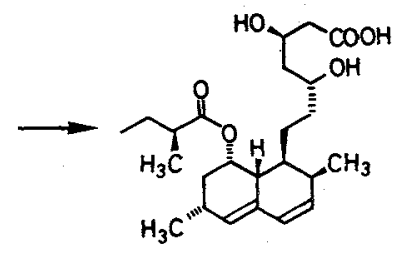

Monacolin K 
Fig. 2. Conversion of monacolin $\mathrm{J}$ to monacolin $\mathrm{K}$ by Paecilomyces viridis L-69.

O Monacolin $\mathrm{J}$, - monacolin $\mathrm{K}$.

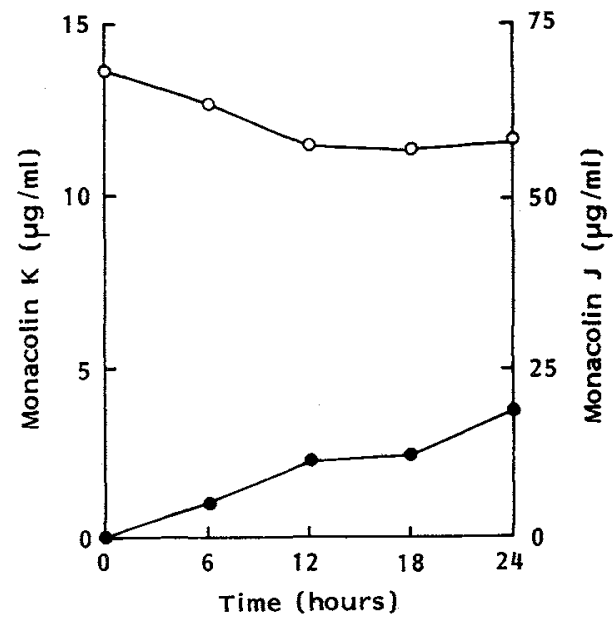

Mycelia of $P$, viridis L-69 were incubated with monacolin $\mathrm{J}$ as described in the text and analyzed by HPLC.

$65 \mu \mathrm{g} / \mathrm{ml}$ ), and aliquots of $0.5 \mathrm{ml}$ of the mixture were submitted to the analysis by HPLC as described above. The results demonstrated that $\sim 4 \mu \mathrm{g} / \mathrm{ml}$ of monacolin $\mathrm{K}$ was produced at the expense of $\sim 10 \mu \mathrm{g} / \mathrm{ml}$ of monacolin $\mathrm{J}$ after 24 hours (Fig. 2). No monacolin $\mathrm{K}$ was detectable when incubated in the absence of monacolin $\mathrm{J}$.

The present experiments have shown that monacolin $\mathrm{K}$ is derived from monacolin $\mathbf{J}$. One possible mechanism for this conversion is esterification of monacolin $\mathrm{J}$ with $\alpha$-methylbutyryl-CoA, resulting in the formation of monacolin $\mathrm{K}$. Another possibility is that monacolin $\mathbf{J}$ is first esterified with $\alpha$-methylacetoacetyl-CoA, followed by reduction, dehydration, and reduction of the side chain ester moiety. This mechanism, which is analogous to the one for fatty acid biosynthesis, is supported by the fact that monacolin $\mathrm{X}$ was isolated from a strain of $M$. ruber $^{3}$. Further study is needed to identify the nature of the conversion of monacolin $\mathbf{J}$ to monacolin $\mathrm{K}$.

P. viridis $\mathrm{L}-69$ produces $\mathrm{ML}-236 \mathrm{~A}$ and compactin
(ML-236B), which are structurally related to monacolin $\mathbf{J}$ and monacolin $\mathrm{K}$, respectively ${ }^{6)}$. Accordingly, it is reasonable that monacolin $\mathrm{J}$ was converted to monacolin $\mathrm{K}$ by $P$. viridis $\mathrm{L}-69$, although this fungus produces no detectable amounts of monacolin $\mathrm{K}$ without exogenously added precursors.

\section{Acknowledgment}

This work was supported in part by a Grant-in-Aid from the Ministry of Education, Science and Culture, Japan.

\section{References}

1) ENDO, A.: Monacolin K, a new hypocholesterolemic agent produced by a Monascus species. J. Antibiotics 32: $852 \sim 854,1979$

2) ENDO, A.: Monacolin K, a new hypocholesterolemic agent that specifically inhibits 3-hydroxy-3-methylglutaryl coenzyme A reductase. J. Antibiotics 33: $334 \sim 336,1980$

3) Endo, A.; K. Hasumi, T. NaKamura, M. Kunishima \& M. MASUDA: Dihydromonacolin L and monacolin $\mathrm{X}$, new metabolites those inhibit cholesterol biosynthesis. J. Antibiotics 38: 321 327, 1985

4) Endo, A.; K. Hasumi \& S. Negishi: Monacolins J and $L$, new inhibitors of cholesterol biosynthesis produced by Monascus ruber. J. Antibiotics 38: $420 \sim 422,1985$

5) Endo, A.; D. Komagata \& H. Shimada: Monacolin M, a new inhibitor of cholesterol biosynthesis. J. Antibiotics 39: 1670 1673, 1986

6) ENDo, A.: Compactin (ML-236B) and related compounds as potential cholesterol-lowering agents that inhibit HMG-CoA reductase. J. Med. Chem. $28: 401 \sim 405,1985$

7) Nakamura, T.; D. Komagata, S. Murakawa, K. SAKAI \& A. ENDO: Isolation and biosynthesis of 3 $\alpha$-hydroxy-3,5-dihydromonacolin L. J. Antibiotics 43: $1597 \sim 1600,1990$

8) Komagata, D; H. Shimada, S. Murakawa \& A. ENDO: Biosynthesis of monacolins: Conversion of monacolin $\mathrm{L}$ to monacolin $\mathrm{J}$ by a monooxygenase of Monascus ruber. J. Antibiotics 42: 407 412, 1989

9) BRADFORD, M. M.: A rapid and sensitive method for the quantitation of microgram quantities of protein utilizing the principle of protein-dye binding. Anal Biochem. 72: $248 \sim 254,1976$ 